International Journal of Advancement in Life Sciences Research

Online ISSN: 2581-4877

journal homepage http://ijalsr.org

Review Article

\title{
Gut microbiota: Succinct overview of impacts on human physique and current research status with future aspects
}

\author{
Md. Imran Hossain ${ }^{1^{*}}$, Redwanul Islam ${ }^{1}$, Sanjida Islam Mimi ${ }^{1}$, Zilhas Ahmed Jewel $^{1,2}$, Utsho Ali \\ Haider $^{3}$ \\ ${ }^{1}$ Department of Biotechnology and Genetic Engineering, Bangabandhu Sheikh Mujibur Rahman Science and \\ Technology University, Gopalganj-8100, Bangladesh \\ 2 Department of Agriculture, Bangabandhu Sheikh Mujibur Rahman Science and Technology \\ University, Gopalganj-8100, Bangladesh \\ ${ }^{3}$ University Hospital Mannheim Heidelberg University, Germany.
}

Correspondence E-mail : imran.bge5@gmail.com*; redwanulislam.bge@gmail.com; sanjidaislammimi@gmail.com; jeweluplb@gmail.com; utsho.ah@outlook.com .

\begin{abstract}
A human body is the excellent example of symbiosis in nature. About $10^{\wedge} 14$ bacteria reside in the human physique as commensal. These microbes make a complex community in entrails is called "gut microbiota". It is estimated that the gut flora is composed more than thousand of different species. These species have various functions in human health and recent research reports on gut microbe's community those have role in the progress and development of major human disease include cancer, obesity, diabetes, autism, mental depression, hypertension etc. In this review we focused the succinct overview on gut microbe's origin, behavior, functions, role in major human disease and the current exploration circumstance with next generation perspective.
\end{abstract}

Keywords: entrails, microbes, microbiota, parasite, immunity, probiotics, diversity, symbiotic, host, dysbiosis.

\section{Introduction}

Like the other symbiotic relationships, human subsistent in a symbiotic relationship with entrails microbiota where human physique provide certain amount nutrition for exist microbes whilst exchange they help in various functions of host (Geurts et al. 2013). In this symbiotic relationship's microbiota ecosystem composed by bacteria, virus, fungi and various type of parasites (Hugon et al. 2015). The entrails microbes harbours at least $10^{\wedge} 11$ to $10^{\wedge} 12$ prokaryotes per gram in stool and it's structure varies with physiologic factor such as dietary habit, age etc(Sullivan et al. 2001).The research on human gut microbes has exploded during the last decade this microbiota has various role in metabolism, human health, immunity within host (Marchesi et al. 2015). Almost 70 disease including for irritable bowel syndrome(IBS)(Malinen et al. 2010), instance obesity (Ley et al. 2006), diabetes type1 (Fallani et al. 2010), cancer Arthur et al. 2012), autism and depression (De et al. 2019, Fond et al. 2015, Zhou and Foster 2015, Natividad and Verdu 2013, de Silva et al. 1991, Wang and Kasper 2014), hypertension (Yang et al. 2015), gout, arthritis, 
ulcer, Alzheimer's disease etc. are directly and indirectly engaged with gut microbiota (Vogt et al. 2017). Moreover, this microbiota has been detected and proposed as a key modulator of human health (Kashyap et al. 2017, Wang et al. 2017).While certain amount changes of this microbiome composition known as "dysbiosis" has been explained the various kind of disease (Lloyd-Price et al. 2016). It is the aim of this work to critically review and summarize recent literature reports on gut microbiota characteristics, functions, role in disease and current research status with future perspectives.

\section{Concise characteristics of entrails Microbiota:}

In general, the human body remain fully sterile at birth, is starting to colonize various microbes is forthwith in contact with fecal,vaginal and skin microbiota of mother where a large amount of microbial community remain (Scaldaferri et al. 2012, Round et al. 2010).

The number of microbiota changes overtime during the dietary habit change, probiotics, prebiotics and various kind of antibiotic uses (Quigley E M 2013, Shen et al. 2016).

As high concentration acids are secreted on stomach and $\mathrm{PH}$ remain very low, the most microorganisms cannot survive there. Normally they inhabit in the last portion of small intestine and whole large intestine. Particularly, red shaped bacteria and grampositive bacteria remain in large amount in the small intestine and the alkali environment remain in large intestine where gram negative bacteria is the dominant group (Sherwood et al. 2013).

The most part of entrails community inhabit on colon and about $60 \%$ dry mass of stool (UoG 2005).

\section{The major microbes in entrails microbiota:}

Prokaryotic diversity: Different species within genera Bacteroidetes, Bifidobacterium, lactobacillus, fusobacterium, peptostreptococcus were dominate at the entrails microbiome community (Mata et al.
1969). Pertaining prokaryotic diversity in host, at least 120 several prokaryotic phyla have been detected and only 31 phyla are cultured species. Moreover, a large number of several species isolated from entrails belong to four phyla Fermicutes, Proteobacteria, Actinobacteria, Bacteroidetes (Hugon et al. 2015).

\section{The Archaeal diversity :}

The archaea diversity constructed the third domain of life different from bacteria and eukarya (Woese et al1990). Finally 8 archaeal species have been identified in human entrails microbial community (Rajilic-Stojanovic and de Vos 2014). Methanobrevibacter ruminantium Nottingham and Hungate 1968), Methanobrevibacter smithii (Dridi et al. 2009), Methanosphaera stadtmanae (Millar et al. 1985), Methanomas siliicoccus luminyensis (Dridi et al. 2012) are the major species in human gut.

\section{Human entrails virome diversity :}

Bacteriophage with double stranded DNA that belong to the order Caudovirales are abundant in gut microbiota and Microviridae bacteriophage which is single stranded DNA are also remain large amount in human gut (Foca et al. 2015). Many viruses those are DNA or RNA including Astorovirus, Rotaryvirus, Calcivirus also found in human gut (Klein et al. 2006).

\section{The Eukaryotic diversity :}

In human gut the taxonomy of eukaryotic community is complex (Clarke et al. 2014, Gibson and Glenn 2004). The five major groups are Amoebazoa, Opisthokanta, Sar, Archaeolastida and Excavata are dominant group in gut microbial community (Adl et al. 2012). In general fungal species including Yeasts and Filamentous fungi are dominant group. The common eukaryotic organisms are Candida albicans, Candida rugosa, Saccharinyces cerevisiae etc also present here (Rajilic-Stojanovic and de Vos 2014, Adl et al. 2012). 
Int J Adv Life Sci Res. Volume 3(2)1-10

Hossain et al.

Table 1: Prokaryotes and Eukaryotic in the human gut

\begin{tabular}{|c|c|}
\hline Phyla & Family \\
\hline \multicolumn{2}{|c|}{ Prokaryotes in human gut } \\
\hline Actinobacteria & 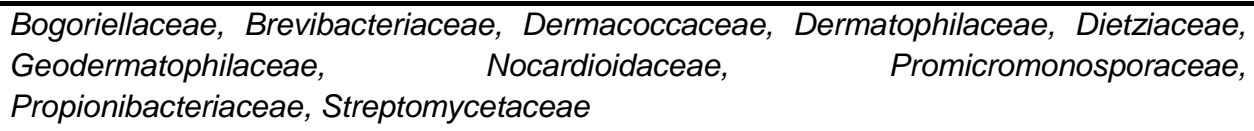 \\
\hline Bacteroidetes & $\begin{array}{l}\text { Flavobacteriaceae, Porphyromonadaceae, } \quad \text { Prevotellaceae, Rikenellaceae, } \\
\text { Sphingobacteriaceae }\end{array}$ \\
\hline Firmicutes & $\begin{array}{l}\text { Carnobacteriaceae, Catabacteriaceae, Christensenellaceae, } \quad \text { Clostridiaceae, } \\
\text { Clostridiales, Enterococcaceae, Erysipelotrichaceae Eubacteriaceae, Lachnospiraceae }\end{array}$ \\
\hline Proteobacteria & $\begin{array}{l}\text { Desulfovibrionaceae, Enterobacteriaceae, } \quad \text { Francisellaceae, Halomonadaceae, } \\
\text { Helicobacteraceae, Legionellaceae, Methylobacteriaceae, Moraxellaceae, Neisseriaceae, } \\
\text { Oxalobacteraceae, Pasteurellaceae, Pseudomonadaceae, Rhizobiaceae, } \\
\text { Rhodobacteraceae, Salinisphaeraceae, Shewanellaceae, Sphingomonadaceae, } \\
\text { Succinivibrionaceae }\end{array}$ \\
\hline \multicolumn{2}{|c|}{ Eukaryotes in the human gut } \\
\hline Fungi & $\begin{array}{l}\text { Candida albicans, Candida famata, Candida glabrata, Candida } \text { guilliermondii, Candid } \\
\text { kefyr, Candida krusei, Candida lambica, Candida lusitaniae, Candida norvogensis, } \\
\text { Candida parapsilosis, Candida pararugosa }\end{array}$ \\
\hline Helminths & Ancylostoma duedonale, Necator americanus, Strongyloides stercorali \\
\hline Protozoa & Endolimax nana, Entamoeba coli, Entamoeba dispar \\
\hline
\end{tabular}

The major functions of entrails microbiota :

In metabolic system : Human would be unable to metabolize all consumed polysaccharide without gut microbiota. Because some important microorganism release some enzymes that breakdown these undigested certain type of polysaccharide (Clarke et al. 2014). Some bacteria convert the carbohydrate into short chain fatty acid by fermentation process (Gibson and Glenn 2004).

Braking the disease causing agent : By fully colonizing and secreting compounds the entrails flora play an important role in defending against the unwelcome microbes for human body (Yoon et al. 2014).

Improvement of protection in immune system : In human physique, the immune system produce the cytokines to create inflammation in order to protect from pathogen (Sommer and Bäckhed 2013).Several bacterial species such as Bacteroides fragilis and some Clostridia help to produce inflammatory cytokines (Reinoso et al. 2016). Gut microbes also play an important role in production of antibody (Mantis et al. 2011).

Bidrectional network Brain axis -gut microbiota: Entrails microbial community act as signaling system between Central Nervous System (CNS) and Gastrointestinal tract (GIT) (Wang et al. 2014). Through the bidirectional communication system, signal from the cerebrum increase the motor, secretory modalities of entrails and conversely the signal from entrails can increase the brain activity (Grenham et al. 2011, Montiel et al. 2013). 
Table 02: Gut microbial products and their potential functions

\begin{tabular}{|c|c|c|}
\hline $\begin{array}{l}\text { Microbial Products } \\
\text { Functions }\end{array}$ & & References \\
\hline Propionates, butyrates & Antineoplastic & $\begin{array}{l}\text { Waldecker et al. } \\
2008\end{array}$ \\
\hline LCA & $\begin{array}{l}\text { Binds to the vitamin } D \text { receptor and acts as } \\
\text { detoxifying agent }\end{array}$ & Sun et al. 2008 \\
\hline Endotoxin & $\begin{array}{l}\text { Changes gut permeability, causes insulin } \\
\text { resistance }\end{array}$ & Fei and Zhao 2013 \\
\hline SBA & $\begin{array}{l}\text { Activates the nuclear famesoid } X \text { receptor (FXR) } \\
\text { and protects against muscle fat deposition }\end{array}$ & Cipriani et al.2010 \\
\hline Capsular polysaccharides (PSA) & Prime $\mathrm{T}$ cell response & $\begin{array}{l}\text { Mazmanian et } \\
\text { al.2008 }\end{array}$ \\
\hline DCA & Causes gallstone formation & Thomas et al. 2000 \\
\hline Butyrates (SCFA) & $\begin{array}{l}\text { Reduces inflammation and prevents ulcerative } \\
\text { colitis }\end{array}$ & Machiels et al. 2013 \\
\hline
\end{tabular}

\section{Roles impact on human health disease :}

Roles on Neuropsychiatric and depression: The dysbiosis and consequent alteration of gut flora produce and spread within bloodstream a potent pro-inflammatory endotoxin, called "lipopolysaccharide(LPS). This small molecule have has an important role in modulation of Central Nervous System (CNS).increase the activity of emotionalism control such as amygdale (Haba et al. 2012). It also produce the cytokines that change the physiological activity of brain (Kastin and Pan 2010).

Involved in cancer: Gut microbiota have role in various cancer as carcinogenic agent (Mager 2006). Bacteroides fragilis which is enterotixigenic that associated with colorectal cancer (Goodwin et al. 2011, Marchesi et al. 2011). Fusobacterium nucleatem also play role in colorectal cancer (Castellarin et al. 2011).

Table 03: Gut microbiota and associated cancers.

\begin{tabular}{lll}
\hline Type of Cancer & Connected Microbe & References \\
\hline Breast cancer & Staphylococus, Enterobacter & Ubraniak et al.2016 \\
Gastric cancer & Helcobacter pylori & Huang et al. 1998 \\
Liver cancer & Hepatitis B virus, hepatitis C virus & Parkin2016 \\
Colon cancer & Citrobacter rodentium & Newman et al. 2001 \\
Cervical cancer & Human papillomavirus alpha type & Bouvard et al. 2009 \\
MALT lymphoma & H. pylori & Cavanna et al. 2008 \\
Colorectal cancer & Streptococcus bovis & Burnett-Hartman et al. 2008 \\
\hline
\end{tabular}

Role in Autism: Through some investigation on autistic children it exploded that some entrails microbial species is linked with autism Finegold et al. 2002, Song et al. 2004, Parracho et al. 2005. The alteration of gut microbiota is directly connected with this disease. Specially Fermicutesc,Bacteroidetes phyla as well as and other entrails commensal such as Bifidobacterium, Sutterella, Prevotella, Lactobacillus, Ruminococcus genera play major role in this disease (Finegold et al. 2010, Adams et al. 2011, Kang et al. 2013, Wang et al. 2013, Williams et al. 2012).

Role in obesity : Through the both in vitro and in vivo studies suggested that the entrails microbiome is directly connected with obesity and play the key role in development of obesity (Le et al. 2013, Sonnenburg and Backhed 2016). Imbalance of Bifidobacterium, Lactobacillus, Enterococcus, $B$ acteroides, Prevotella community develop the obesity of host (Zheng et al. 2018).

Role in Inflammatory Bowel Syndrome(IBS): Entrails microbiota is responsible for this disease specially Firmicutes, Ruminococcus, Clostridium, Dorea, $B$ ifidobacterium, Faecalibacterium genera develop the IBS for being the alteration of normal level in gut (Rajilic-Stojanovic et al. 2011). 
Role in Hypertension : Recent research evidence have claimed that entrails microbiome is the key modulator to maintain the physiological homeostasis. Dysbiosis particularly, increasing the diversity of Fermicutes,Bacteroidetes ratio are directly associated with development of hypertension (Yang et al. 2015).

Role in Diabetes Type 1: The alteration of Clostridium genus (Allin et al. 2018) and Akkermanisa muciniphila level in the gut microbiome is responsible for developing the type-1 diabetes (Hanninen et al. 2017).

Role in Gout: Comparism between normal human and gout patient, scientists revealed that the higher level Bacteroides caccasae,Bacteroides xylanisolvens are present in gout patient. Again Bifidobacterium pseudocatenulatum and Faecalibacterium prausnitzii were found in lower number in gout patient (Jie et al. 2017).

Cardiovascular disease :The entrails microbiota also have been associated with Atherosclerotic Cardiovascular Disease (ACVD),specially Enterobacteriaceae and Streptococcus species is associated with ACVD (Jie et al. 2017).

Alzheimer's disease(AD) : Through the investigation of Alzheimer's patient it revealed that the alteration of Fermicutes, Bifidobacterium and Bacteroidetes were connected and increased the $\mathrm{AD}$ (Vogt et al. 2017).

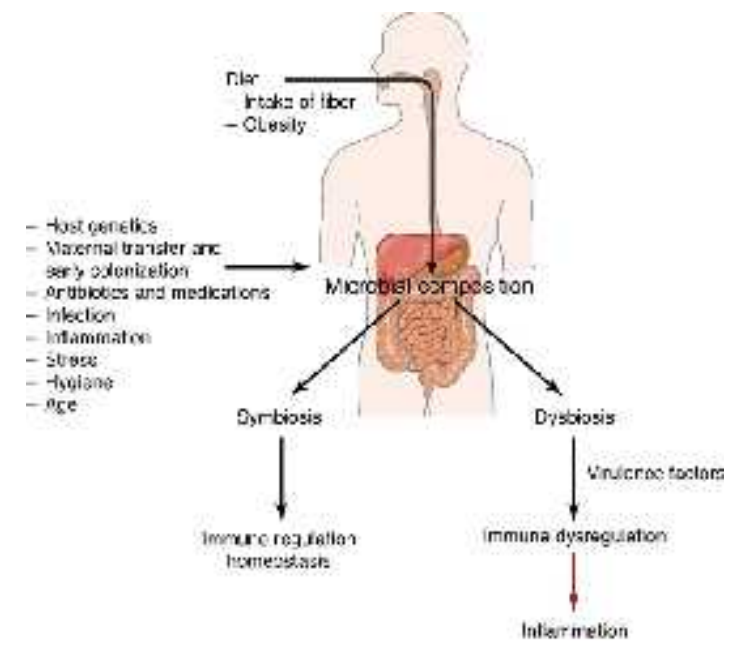

Figure 1:Process of gut microbiota impact on human health (Maslowski et al. 2011)

\section{Current research status and future aspects on gut microbiota:}

The current goal is to differentiate the host microbiota enabling the investigation of it's variation according to factors such as genotype,profile,nutrition, population as well as exposure to.mediation. The worldwide globally scientific and commercial interest on interaction between human and it's associated microbes (Seksik et al. 2006; Sokol et al. 2007; Penders et al. 2007). In the last decades, there has been a bulge in research on gut microbiota and revealed how microbiome community interfere on human health and disease progression (Fischbach MA 2018). Based on.analysing the interaction on synthetic entrails microbiota called a "bottom up" approach that using the Lotavoltermodel has been claimed the interaction pathway and mechanism of gut microbial community. Therefore, this is may be more appropriate to predict the ability of specific probiotics to persist in entrails (Abreu et al. 2018; Venturelli et al. 2018). In recent studies shown that the use of both symbiotics and multistrain probiotics confer the longer lasting effectiveness compared to single species probiotics. It could be an emarging and interesting research area in future (Bambury et al. 2018). Additionally, it could be also interesting to invent the safe and much beneficiable probiotics (Bafeta et al. 2018). Also it would be more effective against the various disease is manipulate the microbiome in entrails to improve the human health (Joglekar and Segre 2017).

\section{Conclusion:}

Albeit the symbiotic relationship of a human body with gut micorbes has been explored for decades, recent research on gut microbiota revealed the various unknown functions and role in human health. This community contains the ten fold more cells than the human body and 100 times the count of genes than the human genome. This entrails community play directly or indirectly almost all type of major severe human disease. At present researchers finding the interaction pathway of gut microbes for establish the treatment procedure more efficient and effective than others conventional procedure by inhibiting or 
regulating these metabolic intersection pathway.

Acknowledgments: The authors would like to thank the department of Biotechnology and Genetic Engineering, Bangabandhu Sheikh Mujibur Rahman Science and Technology

\section{References}

Abreu C., Ortiz Lopez A., Gore J. (2018). Pairing off: a bottom-up approach to the human gut microbiome. Mol Syst Biol,14, e8425.

Adams J.B., Johansen L.J., Powell L.D., Quig D., Rubin R.A. (2011). Gastrointestinal flora and gastrointestinal status in children with autism-comparisons to typical children and correlation with autism severity. BMC Gastroenterol, 11, 22 [PMID:21410934 DOI:10.1186/1471-230X-11-22]

Adl S.M., Simpson A.G., Lane C.E., Lukes J., Bass D., Bowser S.S., et al.(2012). The revised classification of eukaryotes. The Journal of Eukaryotic Microbiology, 59(5),429-93. Epub 2012/10/02. doi: 10.1111/j.15507408.2012.00644.x. PubMed PMID: 23020233; PubMed Central PMCID: PMC3483872.

Allin, K. H., Tremaroli, V., Caesar, R., Jensen, B. A. H., Damgaard, M. T. F., Bahl, M. I., Licht, T. R., Hansen, T. H., Nielsen, T., Dantoft, T. M., Linneberg, A., Jørgensen, T., Vestergaard, H., Kristiansen, K., Franks, P. W., Hansen, T., Bäckhed, F., Pedersen, O., IMI-DIRECT consortium, \& Jørgensen, T. (2018). Aberrant intestinal microbiota in individuals with prediabetes. Diabetologia, 61(4), 810-820. https://doi.org/10.1007/s00125-018-4550-1.

Bafeta A., Koh M., Riveros C., Ravaud P. (2018). Harms reporting in randomized controlled trials of interventions aimed at modifying microbiota: a systematic review. Ann Intern Med,169, 240e7.

Bambury A., Sandhu K., Cryan J.F., Dinan T.G.(2018) Finding the needle in the haystack: systematic identification of psychobiotics. $\mathrm{Br} J$ Pharmacol, 15, 1e9.

Bouvard V., Baan R., Straif K., et al., (2009). A review of human carcinogens-part B: biological agents. Lancet Oncol. 10, 321-322.

Burnett-Hartman A.N., Newcomb P.A., Potter J.D., (2008). Infectious agents and colorectal cancer: a review of Helicobacter pylori, Streptococcus bovis, JC virus, and human papillomavirus. Cancer Epidemiol. Biomarkers Prev. 17, 2970-2979.

Castellarin M., Warren R.L., Freeman J.D., et al., (2011). Fusobacterium nucleatum infection is
University, Gopalganj, Bangladesh for supporting and discussion about this review.

Conflicts of Interest: The authors declare that the research review was conducted in the absence of any commercial or economic associations that could be construed as a potential conflict of interest

prevalent in human colorectal carcinoma. Genome Res. 22, 299.

Cavanna L., Pagani R., Seghini P., et al., (2008). High grade B-cell gastric lymphoma with complete pathologic remission after eradication of Helicobacter pylori infection: report of a case and review of the literature. World J. Surg. Oncol. 6, 35.

Cipriani S., Mencarelli A., Palladino G., Fiorucci S.(2010). Apr. FXR activation reverses insulin resistance and lipid abnormalities and protects against liver steatosis in Zucker (fa/fa) obese rats. J. Lipid Res. 51(4), 771-784.

Clarke Gerard, Stilling Roman M., Kennedy Paul J., Stanton Catherine, Cryan John F., Dinan Timothy G. (2014). Minireview: Gut Microbiota: The Neglected Endocrine Organ. Molecular Endocrinology. $28 \quad(8), \quad 122138$. doi:10.1210/me.20141108. PMC 5414803. PMID 24892638

de Silva H.J., Millard P.R., Soper N., Kettlewell M., Mortensen N., Jewell D.P.(1991). Effects of the faecal stream and stasis on the ileal pouch mucosa. Gut, 32, 1166-1169 [PMID: 1955172]

De, M., Bhattacharya, M., Saha, A., Basu, I., Ganguli, S., \& Dey, S. (2019). Influence of Oral Microbiome on Human Health: an Overview. International Journal of Advancement in Life Sciences Research, 2(1), 16-21. Doi: https://doi.org/10.31632/ijalsr.2019v02i01.003.

Dridi B., Fardeau M.L., Ollivier B., Raoult D., Drancourt M.(2012). Methanomassiliicoccus luminyensis gen. nov., sp. nov., a methanogenic archaeon isolated from human faeces. International Journal of Systematic and Evolutionary Microbiology. 62(Pt 8), 1902-7. Epub 2012/08/04. doi: $10.1099 /$ ijs.0.033712-0. PubMed PMID: 22859731

Dridi B., Henry M., Khechine A. E. I.,Raoult D., Drancourt M. (2009). High prevalence of 616 Methanobrevibacter smithii and Methanosphaera stadtmanae detected in the human gut using 617 an improved DNA detection protocol. PloS one. 2009;4(9):e7063. Epub 2009/09/18. doi: 618 10.1371/journal.pone.0007063. PubMed PMID: 
19759898; PubMed Central PMCID:619 PMC2738942. 620

Fallani, M., Young, D., Scott, J., et al., (2010). Intestinal microbiota of 6-week-old infants across Europe: geographic influence beyond delivery mode, breastfeeding, and antibiotics. J. Pediatr. Gastroenterol. Nutr. 51, 77-84.

Fei, N., Zhao, L., 2013. An opportunistic pathogen isolated from the gut of an obese human causes obesity in germfree mice. ISME J. 7, 880-884.

Finegold S.M., Dowd S.E., Gontcharova V., Liu C., Henley K.E., Wolcott R.D., Youn E., Summanen P.H., Granpeesheh D., Dixon D., Liu M., Molitoris D.R., Green J.A. (2010). Pyrosequencing study of fecal microflora of autistic and control children. Anaerobe, 16, 444-453 [PMID:20603222 DOI: 10.1016/j.anaerobe.2010.06.008]

Finegold S.M., Molitoris D., Song Y., Liu C., Vaisanen M.L., Bolte E., McTeague M., Sandler R., Wexler H., Marlowe E.M., Collins M.D., Lawson P.A., Summanen P., Baysallar M., Tomzynski T.J., Read E., Johnson E., Rolfe R., Nasir P., Shah H., Haake D.A., Manning P., Kaul A.(2002).Gastrointestinal microflora studies in lateonset autism. Clin Infect Dis, 35, S6-S16 [PMID: 12173102 DOI: $10.1086 / 341914]$

Fischbach M.A. Microbiome: focus on causation and mechanism. Cell 2018;174:785e90.

Foca A., Liberto M.C., Quirino A., Marascio N., Zicca .E, Pavia G. (2015). Gut inflammation and immunity: what is the role of the human gut virome? Mediators of inflammation. 326032, Epub 2015/05/07. doi: $10.1155 / 2015 / 326032$. PubMed PMID: 25944980; PubMed Central PMCID: PMC4405218

Fond G., Boukouaci W., Chevalier G., Regnault A., Eberl G., Hamdani N., Dickerson F., Macgregor A., Boyer L., Dargel A., Oliveira J., Tamouza R., Leboyer M. (2015). The "psychomicrobiotic": Targeting microbiota in major psychiatric disorders: A systematic review. Pathol Biol (Paris), 63, 35-42. [PMID: 25468489 DOI:10.1016/j.patbio.2014.10.003]

Geurts L., Neyrinck A.M., Delzenne N.M., Knauf C., Cani P.D. (2015). Gut microbiota controls adipose tissue expansion, gut barrier and glucose metabolism: novel insights into molecular targets and interventions using prebiotics. Benef Microbes, $1 \mathrm{e} 15$.

Gibson Glenn R. (2004). Fibre and effects on probiotics (the prebiotic concept). Clinical Nutrition Supplements. $\quad 1(2), \quad 2531$. doi:10.1016/j.clnu.2004.09.005.
Goodwin A.C., Destefano Shields C.E., Wu S., et al., (2011). Polyamine catabolism contributes to enterotoxigenicBacteroides fragilis-induced colon tumorigenesis. Proc. Natl. Acad. Sci. USA 108, 15354-15359.

Grenham S., Clarke G., Cryan J.F., Dinan T.G. (2011). Brain-gut-microbe communication in health and disease. Front Physiol 2011;2:94.

Guo Z., Zhang J., Wang Z., Ang K.Y., Huang S., Hou Q. (2016). Intestinal microbiota distinguish gout patients from healthy humans. Sci Rep, 6:20602e12.

Haba R., Shintani N., Onaka Y., Wang H., Takenaga R., Hayata A., Baba A., Hashimoto H. (2012). Lipopolysaccharide affects exploratorybehaviors toward novel objects by impairing cognition and/ormotivation in mice: Possible role of activation of the centralamygdala. Behav Brain Res, 228, 423-431. [PMID: 22209851DOI: 10.1016/j.bbr.2011.12.027].

Hamad I., Raoult D., Bittar F.(2015). Repertory of Eukaryotes (Eukaryome) in the Human Gastrointestinal Tract: Taxonomy and Detection Methods. Parasite Immunology. Epub 2015/10/06. doi: 10.1111/pim.12284. PubMed PMID: 26434599.

Hanninen A., Toivonen R, P. € oysti, Belzer C., Plovier H.(2017) €Akkermansia muciniphila induces gut microbiota remodeling and controls islet autoimmunity in NOD mice. Gut, 67, 1445e53.

Huang J.Q., Sridhar S., Chen Y., et al., (1998). Meta-analysis of the relationship between Helicobacter pyloriseropositivity and gastric cancer. Gastroenterology 114, 1169-1179.

Hugon P., Dufour J.C., Colson P., Fournier P.E., Sallah K., Raoult D. (2015). A comprehensive 436 repertoire of prokaryotic species identified in human beings. The Lancet Infectious diseases. 437, 15(10),1211-9. doi: 10.1016/S1473-3099(15)002935. PubMed PMID: 26311042.

Hugon P., Dufour J.C., Colson P., Fournier P.E., Sallah K., Raoult D. (2015). A comprehensive repertoire of prokaryotic species identified in human beings. The Lancet Infectious diseases. 15(10), 1211-9. doi: 10.1016/S1473-3099(15)00293-5. PubMed PMID: 26311042

Jie Z., Xia H., Zhong S., Feng Q., Li S., Liang S., et al. (2017). The gut microbiome in atherosclerotic cardiovascular disease. Nat Commun, 8,845e57.

Joglekar P., Segre J.A. (2017). Building a translational microbiome toolbox. Cell,169,378e8.

Kang D.W., Park J.G., Ilhan Z.E., Wallstrom G., Labaer J., Adams J.B., Krajmalnik-Brown R. (2013). Reduced incidence of Prevotella and other 
fermenters in intestinal microflora of autistic children. PLoS One, 8, e68322 [PMID: 23844187 DOI: 10.1371/journal.pone.0068322]

Kashyap P.C., Chia N., Nelson H., Segal E., Elinav E.(2017). Microbiome at the frontier of personalized medicine. Mayo Clin Proc, 92,1855e64.

Kastin A.J., Pan W. (2010). Concepts for biologically active peptides. CurrPharm, 16, 33903400 [PMID: 20726835]

Klein E.J., Boster D.R., Stapp J.R., Wells J.G., Qin X., Clausen C.R., et al. (2006). Diarrhea etiology in a Children's Hospital Emergency Department: a prospective cohort study. Clin Infect Dis. 43(7),80713. doi: 10.1086/507335. PubMed PMID: 16941358.

Kostic, A. D., Chun, E., Robertson, L., Glickman, J. N., Gallini, C. A., Michaud, M., Clancy, T. E., Chung, D. C., Lochhead, P., Hold, G. L., El-Omar, E. M., Brenner, D., Fuchs, C. S., Meyerson, M., \& Garrett, W. S. (2013). Fusobacterium nucleatum potentiates intestinal tumorigenesis and modulates the tumor-immune microenvironment. Cell host \& microbe, 14(2), 207-215. https://doi.org/10.1016/j.chom.2013.07.007

Le CE, Nielsen T, Qin J, Prifti E, Hildebrand F, Falony G. (2013). Richness of human gut microbiome correlates with metabolic markers. Nature, 500, 541e6.

Ley R. E., Turnbaugh P.J, Klein S, Gordon J.I. (2006). Microbial ecology: human gut microbes associated with obesity. Nature, 444(7122), 1022-3. doi: 10.1038/4441022a. PubMed PMID: 17183309

Lloyd-Price J., Abu-Ali G., Huttenhower C. (2016). The healthy human microbiome. Genome Med,8,1e11.

Machiels K., Joossens M., Sabino J., et al., (2013). A decrease of the butyrate-producing species Roseburia hominis and Faecali-bacterium prausnitzii defines dysbiosis in patients with ulcerative colitis. Gut 63, 1275-1283.

Mager D.L. (2006). Bacteria and cancer: cause, coincidence or cure? A review. J. Transl. Med. 4, 14.

Malinen E, Krogius-Kurikka L., Lyra A., Nikkila J., Jaaskelainen A., Rinttila T., et al. (2010). Association of symptoms with gastrointestinal microbiota in irritable bowel syndrome. World Journal of Gastroenterology : WJG. 16(36), 453240. PubMed PMID: 20857523; PubMed Central PMCID: PMCPMC2945484

Mantis N. J., Rol N., Corthésy B. (2011). Secretory IgA's complex roles in immunity and mucosal homeostasis in the gut. Mucosal Immunology. 4 (6),
603, 11. doi:10.1038/mi.2011.41. PMC 3774538. PMID 21975936

Marchesi J. R., Adams D. H., Fava F., Hermes G. D., Hirschfield G.M., Hold G., et al. (2015). The gut microbiota and host health: a new clinical frontier. Gut. doi: 10.1136/gutjnl-2015-309990. PubMed PMID: 26338727.

Marchesi J.R., Dutilh B.E., Hall N., et al., (2011). Towards the human colorectal cancer microbiome. PLoS One 6,e2044.

Maslowski K.M., Mackay C.R. (2011). Diet, gut microbiota and immune responses. Nat Immunol, 12, 5-9.

Mata L.J., Carrillo C., Villatoro E.(1969). Fecal microflora in health persons in a preindustrial region. Appl Microbiol. 17(4), 596-602. PubMed PMID: 4890749; PubMed Central PMCID: PMCPMC377749.

Mazmanian S.K., Round J.L., Kasper D.L., (2008). A microbial symbiosis factor prevents intestinal inflammatory disease. Nature 453, 620-625.

Miller T.L., Wolin M.J. (1985). MethanosphaeraStadtmaniae Gen-Nov, Sp-Nov - a Species That Forms Methane by Reducing Methanol with Hydrogen. Arch Microbiol. 141(2), 116-22. doi: Doi 10.1007/Bf00423270. PubMed PMID: WOS:A1985AHM2800003.

Montiel-Castro A.J., Gonzalez-Cervantes R.M., Bravo-Ruiseco G., Pacheco-Lopez G. (2013). The microbiota-gut-brain axis: neurobehavioral correlates, health and sociality. Front Integr Neurosci 7, 70.

Natividad J.M., Verdu E.F. (2013). Modulation of intestinal barrier by intestinal microbiota: pathological and therapeutic implications. Pharmacol Res, 69, 42-51. [PMID: 23089410 DOI: 10.1016/

j.phrs.2012.10.007]

Newman J.V., Kosaka T., Sheppard B.J., et al., (2001). Bacterial infection promotes colon tumorigenesis inApc(Min/+) mice. J. Infect. Dis. 184, 227-230.

Nottingham P.M., Hungate R.E. (1968). Isolation of methanogenic bacteria from feces of man. 613 Journal of bacteriology. 96(6), 2178-9. Epub 1968/12/01. PubMed PMID: 4881707; 614 PubMed Central PMCID: PMC252579. 615

Parkin D.M.,(2006). The global health burden of infection-associated cancers in the year 2002. Int. J. Cancer 118, 3030-3044.

Parracho H.M., Bingham M.O., Gibson G.R., Mc Cartney AL. (2005). Differences between the gut 
microflora of children with autistic spectrum disorders and that of healthy children. $J$ Med Microbiol, 54, 987-991 [PMID: 16157555 DOI: 10.1099/jmm.0.46101-0]

Penders J., Stobberingh E.E., Van den Brandt P.A., et al.(2007). The role of intestinal microbiota in the development of atopic disorders. Allergy, 62,122336.

Quigley, E. M (2013). "Gut bacteria in health and disease". Gastroenterology \& hepatology. 9 (9): 560 9. PMC 3983973. PMID 24729765

Rajilic-Stojanovic M., de Vos W.M. (2014). The first 1000 cultured species of the human gastrointestinal microbiota. FEMS microbiology reviews. 38(5),9961047. Epub 2014/05/28. doi: 10.1111/15746976.12075. PubMed PMID: 24861948; PubMed Central PMCID: PMC4262072.

Rajilic-Stojanovic, M., Biagi, E., Heilig, H., Kajander, K., Kekkonen, R., Tims, S. et al. (2011). Global and deep molecular analysis of microbiota signatures in fecal samples from patients with irritable bowel syndrome. Gastroenterology, 141, 1792-1801.

Reinoso Webb Cynthia, Koboziev lurii, Furr Kathryn L, Grisham Matthew B. (2016). Protective and proinflammatory roles of intestinal bacteria. Pathophysiology. $23 \quad$ (2), $\quad 67-\quad 80$. doi:10.1016/j.pathophys.2016.02.002. PMC 4867289. PMID 26947707

Round J.L., O'Connell R.M., Mazmanian S.K. (2010). Coordination of tolerogenic immune responses by the commensal microbiota. $J$ Autoimmun; 34, J220-J225 [PMID: 19963349 DOI:10.1016/j.jaut.2009.11.007]

Scaldaferri F, Pizzoferrato M, Gerardi V, Lopetuso L, Gasbarrini A. (2012). The gut barrier: new acquisitions and therapeutic approaches. J Clin Gastroenterol, 46 Suppl: S12-S17 [PMID: 22955350 DOI:10.1097/MCG.0b013e31826ae849]

Seksik P., Sokol H., Lepage P. et al.(2006). Review article: the role of bacteria in onset and perpetuation of inflammatory bowel disease. Aliment Pharmacol Ther, 24(Suppl. 3), 118.

Shen Sj., Wong, Connie H.Y. (2016). "Bugging inflammation: Role of the gut microbiota". Clinical \& Translational Immunology, 5 (4), e72. doi:10.1038/cti.2016.12.

Sherwood Linda, Willey Joanne, Woolverton Christopher (2013). Prescott's Microbiology (9th ed.). New York: McGraw Hill. pp. 713-21. ISBN 9780073402406. OCLC 886600661.
Sokol H., Lepage P., Seksik P., Dore J., Marteau P. (2007). Molecular comparison of dominant microbiota associated with injured versus healthy mucosa in ulcerative colitis. Gut, 56, 152-4.

Sommer Felix, Bäckhed Fredrik (2013). The gut microbiota - masters of host development and physiology. Nature Reviews Microbiology. 11 (4): 22738. doi:10.1038/nrmicro2974. PMID 23435359.

Song Y., Liu C., Finegold S.M. (2004). Real-time PCR quantitation of clostridia in feces of autistic children. Appl Environ Microbiol, 70, 6459-6465 [PMID: 15528506 DOI: 10.1128/AEM.70.11.64596465.2004]

Sonnenburg J.L., Backhed F.(2016). Dietmicrobiota interactions as €moderators of human metabolism. Nature, 535, 56e64.

Sullivan A., Edlund C., Nord C.E. (2001). Effect of antimicrobial agents on the ecological 433 balance of human microflora. The Lancet Infectious diseases.1(2), 101-14. Epub 434 2002/03/02. doi: 10.1016/S1473-3099(01)00066-4. PubMed PMID: 11871461.

Sun J., Mustafi R., Cerda S., et al., (2008). Lithocholic acid down-regulation of NF-kappa B activity through vitamin $\mathrm{D}$ receptor in colonic cancer cells. J. Steroid Biochem. Mol. Biol. 111, 37-40.

Thomas L.A., Veysey M.J., Bathgate T., et al., (2000). Mechanism for the transit-induced increase in colonicdeoxycholic acid formation in cholesterol cholelithiasis. Gastroenterology 119, 806-815.

Ubraniak C., Gloor G.B., Brackstone M., et al., (2016). The microbiota of breast tissue and its association withtumours. Appl. Environ. Micro. 82, 5039-5048.

University of Glasgow. (2005). The normal gut flora. Available through web archive. Accessed May 22, 2008

Venturelli O.S., Carr A.C., Fisher G., Hsu R.H., Lau R., Bowen B.P., et al. (2018). Deciphering microbial interactions in synthetic human gut microbiome communities. Mol Syst Biol,14, e8157.

Vogt N.M., Kerby R.L., Dill-Mc Farland K.A., Harding S.J., Merluzzi A.P, Johnson S.C., Carlsson C.M., Asthana S., Zetterberg H., Blennow K. et al. (2017). Gut microbiome alterations in Alzheimer's disease. Sci Rep, 7,1-11.

Vogt N.M., Kerby R.L., Dill-Mc Farland K.A., Harding S.J., Merluzzi A.P., Johnson S.C., Carlsson C.M., Asthana S., Zetterberg H., Blennow K. et al.(2017). Gut microbiome alterations in Alzheimer's disease. Sci Rep, 7,1-11. 
Waldecker M., Kautenburger T., Daumann H., et al., (2008). Inhibition of histone-deacetylase activity by short-chain fatty acids and some polyphenol metabolites formed in the colon. J. Nutr. Biochem. 19, 587-593.

Wang B., Yao M., Lv L., Ling Z., Li L. (2017). The human microbiota in health and disease. Engineering, 3,71e82.

Wang L., Christophersen C.T., Sorich M.J., Gerber J.P., Angley M.T., Conlon M.A. (2013). Increased abundance of Sutterella spp. and Ruminococcus torques in feces of children with autism spectrum disorder. Mol Autism, 4, 42. [PMID: 24188502 DOI:10.1186/2040-2392-4-42]

Wang Y., Kasper L.H.(2014). The role of microbiome in central nervous system disorders. Brain Behav Immun, 38, 1-12. DOI: 10.1016/j.bbi.2013.12.015.

Wang Yan, Kasper Lloyd H. (2014). The role of microbiome in central nervous system disorders. Brain, Behavior, and Immunity. 38, 1-12. doi:10.1016/j.bbi.2013.12.015. PMC 4062078. PMID 24370461.

Williams B.L., Hornig M., Parekh T., Lipkin W.I. (2012). Application of novel PCR-based methods for detection, quantitation, and phylogenetic characterization of Sutterella species in intestinal biopsy samples from children with autism and gastrointestinal disturbances. MBio, 3, pii: e0026111 [PMID: 22233678 DOI: 10.1128/mBio.00261-11]
Woese C.R., Kandler O., Wheelis M.L.(1990). Towards a natural system of organisms: proposal for the domains Archaea, Bacteria, and Eucarya. Proceedings of the National Academy of Sciences of the United States of America. 87(12), 4576-9.

Yang T., Santisteban M., Rodriguez V., Li E., Ahmari N., Carvajal J.M. (2015). Gut dysbiosis is linked to hypertension. Hypertension, 65, $1331 \mathrm{e} 40$.

Yang T., Santisteban M., Rodriguez V., Li E., Ahmari N., Carvajal J.M. (2015). Gut dysbiosis is linked to hypertension. Hypertension, 65,1331e40.

Yoon My Young, Lee Keehoon, Yoon Sang Sun (2014). Protective role of gut commensal microbes against intestinal infections. Journal of Microbiology. 52(12), 983-9. doi:10.1007/s12275-014-4655-2. PMID 25467115.

Zheng $X$, Zhu J, Zhang X, Cheng M, Zhang Z, Cao J. (2018). The modulatory effect of nanocomplexes loaded with EGCG3 Me on intestinal microbiota of high fat diet-induced obesity mice model. J Food Biochem, 42,1e8.

Zhou L, Foster JA. Psychobiotics and the gut-brain axis: in the pursuit of happiness. Neuropsychiatr Dis Treat (2015). 11, 715-723. PMID: 25834446 DOI: 10.2147/NDT.S61997 